\title{
THE PROPERTY (RELATIONSHIPS) ACT 1976 AND TRUSTS: PROPOSALS FOR REFORM
}

\author{
Nicola Peart*
}

Trusts often have the effect of undermining the social aims of the Property (Relationships) Act 1976. In the absence of legislative action, the courts have been sympathetic to a range of arguments aimed at accessing trust assets that would have been subject to division between the parties but for the trust. None of these judicial responses adequately addresses the current deficiencies of the Property (Relationships) Act or the potential detriment to trusts and their beneficiaries. This paper considers a range of potential reforms and argues that any reform should seek to strike a balance between the social aims of a relationship property regime and the right of owners to structure their property interests as they wish.

\section{INTRODUCTION}

Trusts are very common in New Zealand, more so than in any other common law country it seems. ${ }^{1}$ When couples separate, assets acquired during the relationship or associated with it are often held in trust. But for the trust, some or all of those assets would be relationship property and subject to the equal sharing regime of the Property (Relationships) Act 1976 (PRA). As these trusts are normally discretionary in nature, the parties to the relationship do not own the trust property. On trust law principles they have at most a hope or expectation that the trustees will exercise their discretion in favour of one or both of the parties to the relationship. ${ }^{2}$ As the PRA applies only to

* Professor of Law, University of Otago. I am grateful to academic and professional colleagues from around the country for engaging with me on this complex topic, especially Associate Professor Jessica Palmer. Thank you also to Andrew Snoddy JD, Research Assistant, Faculty of the Law, University of Otago, for locating relevant materials for this article.

1 Law Commission Some Issues with the use of Trusts in New Zealand: Review of the Law of Trusts Second Issues Paper (NZLC IP20, 2010) at 2.1-2.7.

2 Gartside v Inland Revenue Commissioners [1968] AC 553 (HL) has been followed in Hunt v Muollo [2003] 2 NZLR 322 (CA); Johns v Johns [2004] 3 NZLR 202 (CA); Kain v Hutton [2008] NZSC 61, [2008] 3 NZLR 589; and in the PRA context Nation $v$ Nation [2005] 3 NZLR 46 (CA) at [148]. 
property that is beneficially owned by either of the parties, property held in discretionary trusts ${ }^{3}$ is generally outside the scope of the PRA. ${ }^{4}$ Remedies for dealing with dispositions to trusts in ss 44 and $44 \mathrm{C}$ of the PRA are limited in scope and do little to redress the exodus of assets from the PRA's reach. The courts also have power under s 182 of the Family Proceedings Act 1980 (FPA) to make orders in relation to nuptial settlements, but that provision is available only to spouses and civil union partners, not de facto partners, and the court's discretion is not subject to the equal sharing principles that underpin the PRA.

The detrimental effect of trusts on the relationship property rights of spouses and partners is well known, but the Legislature has done little so far to remedy the situation. The courts have been sympathetic to a range of arguments aimed at directly or indirectly accessing trust property in the context of a relationship dispute, but few have ultimately succeeded. A recent ruling of the Supreme Court that a husband's combination of powers in relation to a trust constituted "property" within the meaning of the PRA may reduce some of the frustration, but it is unlikely to provide a satisfactory answer in all cases. ${ }^{5}$ In the same case, but in a separate judgment, the Supreme Court also expanded the scope of the courts' jurisdiction and discretion in s 182 FPA, but it too will assist only some applicants. ${ }^{6}$

In its Review of Trust Law, the New Zealand Law Commission recommended amending s 44C PRA and s 182 FPA to give the courts wider powers to make orders in respect of trusts, but it acknowledged that a full review of the PRA might be needed to address these matters properly. ${ }^{7}$ In November 2015 the Minister of Justice referred the PRA to the Law Commission for review. The terms of reference are broad, going well beyond the issue of trusts. This paper, however, will focus on the interface between relationship property law and trust law.

The article will first briefly outline the current legal position to clarify the problem that trusts presently pose when dividing property on the breakdown of a relationship. It will then analyse the Law Commission's proposed reforms to s 44C PRA and s 182 FPA and their potential impact on three different types of trusts: a Couple's Trust settled by a couple with relationship property; a Single's Trust settled by a single person with property owned by that person, and a Parents' Trust

3 The term "discretionary trust" is used here to include mere powers of appointment where trustees are not under a duty to distribute: McPhail v Doulton [1971] AC 424 (HL).

4 See the definitions of "owner" and "property" in the Property (Relationships) Act 1976, s 2, discussed further below. See also Bill Atkin's discussion of the meaning of "property" in "What Kind of Property is 'Relationship Property'?" (2016) 3 VUWLR 345.

5 Clayton v Clayton [Vaughan Road Property Trust] [2016] NZSC 29, [2016] 1 NZLR 551 [Clayton VRPT (SC)]. The ruling is discussed further below and in Atkin, above $\mathrm{n} 4$.

6 Clayton v Clayton [Claymark Trust] [2016] NZSC 30, [2016] 1 NZLR 590 [Clayton CT (SC)].

7 Law Commission Review of the Law of Trusts: A Trusts Act for New Zealand (NZLC R130, 2013) at ch 19. 
settled by parents with assets from the parents to which the couple may or may not have contributed during the relationship. This analysis will reveal a number of concerns, particularly with the Law Commission's proposed reform to s 44C PRA. The article will then consider other, more radical, reforms that the Law Commission might propose in its review of the PRA and assess their potential consequences for the three types of trusts. I will argue that any reforms to the PRA and s 182 FPA should aim to strike a balance between the social objectives of a property sharing regime between former spouses and partners and the rights of property owners to structure their property interests as they wish and have those structures upheld.

\section{CURRENT POSITION}

The current law governing property division between former spouses, civil union partners and de facto partners (spouses and partners) has its origin in the Matrimonial Property Act 1976. That Act introduced the idea of marriage being a partnership of equals to which each partner was presumed to contribute equally, albeit in different ways, and hence the principle of equal sharing of the property associated with the partnership on separation or divorce. ${ }^{8}$ The Matrimonial Property Act was amended in 2001 to strengthen the equal sharing regime, to include de facto relationships that had endured for more than three years, and to extend the regime to relationships ending on death. ${ }^{9}$ The Act was renamed the Property (Relationships) Act 1976, but the essence of the equal sharing regime was not changed. ${ }^{10}$

During the relationship, each party is free to deal with his or her assets as he or she wishes. ${ }^{11}$ But on separation the assets that each party beneficially owns are classified as either relationship property or separate property. Relationship property is equally shared subject to limited exceptions, while separate property is retained by the owning spouse, subject to any compensation orders the court may make in favour of the non-owning spouse or partner. ${ }^{12}$ Relationship property is exhaustively defined in the PRA. ${ }^{13}$ It captures the assets produced by the partnership, including any

8 Matrimonial Property Act 1976, long title. Contributions of a monetary nature are presumed to be of no greater value than contributions of a non-monetary nature: $\mathrm{s} 18$.

9 Property (Relationships) Amendment Act 2001. Most of the amended Act came into force on 1 February 2002.

10 Although some of the section numbers have changed, references here are to the Property (Relationships) Act, rather than the Matrimonial Property Act.

11 Property (Relationships) Act 1976, s 19.

12 Sections 11-14AA. The two exceptions to equal division of relationship property are relationships of less than three years duration (ss 14-14AA) and where extraordinary circumstances exist that make equal sharing repugnant to justice (s 13). Compensation may be ordered inter alia for economic disparity (s 15), sustaining separate property (s 17), and dispositions having the effect of defeating the applicant's rights (s 44C).

13 Sections 8-10. 
increase in value of separate property attributable to the application of relationship property or the direct or indirect actions of the non-owning spouse or partner, as well as the family home and family chattels whenever they were acquired. ${ }^{14}$ Property acquired during the marriage from a third party by way of gift, inheritance, survivorship, or as a beneficiary of a trust is not produced by the joint efforts of the spouses and hence is separate property of the owning spouse. ${ }^{15}$ The regime is essentially a deferred community property system. ${ }^{16}$ It applies unless the parties formally contract out of the PRA. ${ }^{17}$

\section{A The PRA and Trusts}

\section{Meaning of property ownership}

The most common form of trust in New Zealand is a discretionary family trust, often settled by one or both of the parties to a marriage, civil union, or de facto relationship, for the benefit of themselves and their children. As distribution from such a trust is at the discretion of the trustees, the conventional view is that the objects of the trust do not beneficially own the assets of the trust prior to distribution in their favour. ${ }^{18}$ The PRA defines "owner" as "the beneficial owner of the property under any enactment or rule of common law or equity". ${ }^{19}$ The trust assets are therefore not property of the parties for purposes of the PRA, even if but for the trust the assets would be relationship property.

The courts have entertained a range of arguments aimed at bringing trust assets or the settlor's powers in relation to the trust within the PRA's meaning of property. "Property" is defined as including real and personal property, any estate or interest in real or personal property, any debt or thing in action, and any other right or interest. ${ }^{20}$ Prior to the recent Supreme Court ruling in Clayton $v$ Clayton in relation to the Vaughan Road Property Trust (Clayton VRPT), arguments to bring trust assets or powers within this definition have generally been unsuccessful. ${ }^{21}$ The sham argument usually fails because the trust deed was not intended to be a pretence or façade to conceal the true

14 Sections 8 and 9A. The family home and chattels are included because of their close association with the marriage relationship.

15 Section 10.

16 AH Angelo and WR Atkin "A Conceptual and Structural Overview of the Matrimonial Property Act 1976" (1977) 7 NZULR 237.

17 Property (Relationships) Act, s 21.

18 Hunt v Muollo, above n 2, at [11]; Johns v Johns, above n 2, at [31]; Kain v Hutton, above n 2, at [25]; and in the PRA context Nation $v$ Nation, above n 2, at [74].

19 Property (Relationships) Act, s 2.

20 Property (Relationships) Act, s 2.

21 Clayton VRPT (SC), above n 5. 
intentions of the settlor and trustees. ${ }^{22}$ The settlor normally intends to create a trust. ${ }^{23}$ The argument that the settlor's retention of extensive powers of control should result in the trust being disregarded as illusory or as the settlor's "alter ego" were rejected as flawed arguments. In Official Assignee v Wilson the Court of Appeal held that the alter ego argument was not a separate cause of action. ${ }^{24}$ It could at most be used as evidence of a sham or some other established cause of action. The Court of Appeal rejected the illusory trust argument in Clayton $v$ Clayton as being no different from the sham argument. ${ }^{25}$ On appeal, however, the Supreme Court opined that the absence of a sham did not necessarily preclude a finding that no trust came into existence if the settlor had such extensive powers over the trust that the property could not be said to have been alienated in favour of another. ${ }^{26}$ It preferred to label such trusts as simply invalid rather than "illusory". ${ }^{27}$ While this argument thus remains viable, there are likely to be few cases where the settlor has retained such extensive powers over the trust that no trust came into existence.

Arguments that retained powers of control in conjunction with a discretionary interest constitute property have had greater success. ${ }^{28}$ These arguments do not purport to access the trust assets directly, but to give those powers independent value. ${ }^{29}$ While these arguments, known as the

22 Ben Nevis Forestry Ventures Ltd v Commissioner of Inland Revenue [2008] NZSC 115, [2009] 2 NZLR 289 at [33]; and Official Assignee v Wilson [2008] NZCA 122, [2008] 3 NZLR 45. In KA No 4 Trustee Ltd v Financial Markets Authority [2012] NZCA 370 at [52] the Court of Appeal did not appear to require fraudulent concealment. It saw merit in the argument that the retention of extensive of powers of control in the hands of one person may suffice to establish a sham.

23 As in the case of the Vaughan Road Property Trust settled by Mr Clayton, which all of the courts agreed was not a sham because Mr Clayton genuinely intended to create a trust: MAC $v$ MAC FC Rotorua FAM2007-063-652, 2 December 2011 at [67]; Clayton v Clayton [2013] NZHC 301, [2013] 3 NZLR 236 at [79]; Clayton v Clayton [2015] NZCA 30, [2015] 3 NZLR 293 [Clayton (CA)] at [67]; and Clayton VRPT (SC), above n 5, at [117]. None of the courts relied on the dictum in KA No 4 Trustee Ltd v Financial Markets Authority, above n 22.

24 Official Assignee v Wilson, above n 22, at [72]. See also Jessica Palmer "Dealing with the emerging popularity of sham trusts" [2007] NZ L Rev 81; and Jessica Palmer "Controlling the trust" (2011) 12 OLR 473.

25 Clayton (CA), above n 23, at [57]-[85]. See Jessica Palmer and Nicola Peart "Clayton v Clayton: a step too far?" (2015) NZFLJ 114, where this ruling is criticised. The decision also received international criticism: Joel Nitikman "Sham, illusion and all that jazz: a case comment on Clayton v Clayton" (2016) 22 Trusts and Trustees 180-189.

26 Clayton VRPT (SC), above n 5, at [123]-[124].

27 At [123].

$28 J G v J B G$ FC North Shore FAM-2007-044-591, 13 July 2010; $R v R$ [2010] NZFLR 555 (FC); and LTEP $v$ JMP (A Bankrupt) [2011] NZFLR 797 (FC).

29 In Walker $v$ Walker [2007] NZCA 30, [2007] NZFLR 772 at [49] the Court of Appeal commented obiter that rights and powers associated with a trust were a valuable "package of assets", because together they 
"bundle of rights" or "package of assets" argument, have been the subject of widespread criticism, ${ }^{30}$ the Supreme Court adopted a more sophisticated version of that argument in Clayton VRPT in relation to the Vaughan Road Property Trust (VRPT), one of many trusts associated with $\mathrm{Mr}$ Clayton's sawmilling business. ${ }^{31}$

Mr Clayton settled the VRPT in 1999 during his marriage with assets mostly accumulated during his marriage. ${ }^{32} \mathrm{He}$ was the sole trustee and he, his wife, and their children were discretionary beneficiaries. ${ }^{33}$ The children were the final beneficiaries. ${ }^{34}$ In his capacity as Principal Family Member ${ }^{35} \mathrm{Mr}$ Clayton had the power to appoint and remove trustees ${ }^{36}$ and discretionary beneficiaries, ${ }^{37}$ but not final beneficiaries. ${ }^{38}$ As trustee he had the power to appoint capital and income to any of the discretionary beneficiaries during the existence of the trust and on vesting day. ${ }^{39} \mathrm{He}$ also had the power to bring the vesting date forward, ${ }^{40}$ and to resettle all or any part of the

conferred control over the company that operated the husband's business. See also Harrison $v$ Harrison [2009] NZCA 68, [2009] NZFLR 687.

30 For example Paul Heath "Some Thoughts on a (New Zealand) Judicial Approach to Trust Law" (Address to STEP New Zealand Conference, 29 March 2012); Anthony Grant "Might the Bundle of Rights Theory Emerge in Another Form?" (2012) 190 NZ Lawyer 13; Shelley Griffiths, "Valuing 'Bundles of Rights' for the Property (Relationships) Act 1976: when neither art nor science is enough" (2011) 7 NZFLJ 98; Mark O'Regan and Andrew Butler "Equity and Trusts in a Family Law Context" (paper presented to the New Zealand Law Society Family Law Conference, November 2011) 267; Palmer "Dealing with the emerging popularity of sham trusts", above n 24; Palmer "Controlling the trust", above n 24; and Charles Rickett "Instrumentalism in the Law of Trusts - The Disturbing Case of the Constructive Trust Upon an Express Trust" (2016) VUWLR 463. But see Frances Gush "The 'Bundle of Rights' - Unravelling Trust Principles" (2012) 7 NZFLJ 157.

31 Clayton VRPT (SC), above n 5.

32 Relevant clauses of the Vaughan Road Property Trust Deed [VRPT] are appended to the Supreme Court decision.

33 Clause 2.1.

34 Clause 2.1

35 Clause 2.1

36 Clause 17

37 Clause 7.1 .

38 The Court of Appeal was in error in thinking that Mr Clayton had the power to remove all the beneficiaries leaving himself as the sole beneficiary and, as he was the sole trustee, thereby bring the trust to an end: Clayton (CA), above n 23, at [88]. The Court of Appeal was therefore wrong to conclude that the power to add and remove beneficiaries on its own gave Mr Clayton a general power of appointment and the Supreme Court overruled the Court of Appeal on this point: Clayton VRPT (SC), above n 5 at [49]. For a critical analysis of the Court of Appeal decision see Palmer and Peart, above $\mathrm{n} 25$.

39 VRPT, above $\mathrm{n} 32$, at cls 4.1, 6.1 and 10.

40 Clause 2.1, definition of "vesting day". 
trust fund in favour of any one or more discretionary beneficiaries. ${ }^{41}$ Furthermore, and unusually, he had the power as trustee to exercise any of the powers and discretions in his own favour. ${ }^{42}$ As is common in discretionary trusts, the VRPT deed excluded several of the default duties that would otherwise constrain the trustee's exercise of powers. As trustee, Mr Clayton had unfettered discretion to exercise the powers and discretions partially, without considering the interests of all beneficiaries and regardless of whether the exercise might be contrary to the interests of any present or future beneficiary. ${ }^{43}$ There was also a clause negating a trustee's conflict of interest, which allowed him to exercise any of the powers and discretions notwithstanding that his interests or duty might conflict with his duty to the trust fund or any beneficiary. ${ }^{44}$

The Supreme Court held that this combination of powers and entitlements gave Mr Clayton such a degree of control over the assets of the VRPT that it was appropriate to classify the powers as rights or interest in terms of the definition of "property" in the PRA. ${ }^{45}$ The combination of powers constituted a general power of appointment, because he could exercise them in his own favour without having to consider the interests of other beneficiaries. ${ }^{46}$ The freedom to self-benefit, and the exclusion of default duties meant there was "no effective constraint on the exercise of powers in favour of himself". ${ }^{47}$ The normal constraints of fiduciary obligations are "not of any practical significance" in relation to his powers as trustee. ${ }^{48}$ As this power was acquired during the marriage, it was relationship property under s $8(1)(e)$ PRA and subject to equal division. ${ }^{49}$ The power was valued as equal to the value of the trust assets and, hence, the effect was that Mrs Clayton was entitled to half the value of the VRPT assets as her relationship property entitlement.

Space does not permit a detailed analysis of this decision, except to observe that if Mr Clayton could not be held accountable for the exercise of his powers, as the Supreme Court suggests, a core

41 Clause 8.1.

42 Clause 14.1: "A Trustee who is also a Beneficiary may exercise any power or discretion vested in the Trustees in his, her, or its favour."

43 Clause 11.1.

44 Clause 19.1(c).

45 Clayton VRPT (SC), above $\mathrm{n}$ 5, at [80].

46 At [59]-[68]. The Court observed that this was a more compelling case to treat powers and entitlements in relation to a trust as property than the Australian case of Kennon v Spry [2008] HCA 56, (2008) 238 CLR 366, decided under the Family Law Act 1975 (Cth).

47 Clayton VRPT (SC), above n 5, at [67].

48 At [64].

49 At [86]. There was no evidence that assets in the VRPT would have been separate property, but for the trust. If there had been, the Court said at [89] that it might have been necessary to consider invoking the exception to equal division in $\mathrm{s} 13$ of the Act. 
element of a trust was missing and the Court should have concluded that the trust was invalid, rather than treating the powers as property. Either way, this decision creates significant uncertainty for other trusts. The VRPT was unusual in the extent of the powers and all of them being held by one person: Mr Clayton. What if the settlor's powers were less extensive? The Court left that question for another day. ${ }^{50}$ However, it did indicate the need for "worldly realism" in the PRA context and an acceptance that strict concepts of property law may not be appropriate in this context. ${ }^{51}$ This comment is likely to encourage a broad application of the ruling in future cases, which may substantially redress the undermining effect of trusts on relationship property claims. Nonetheless, it is unlikely to provide an adequate response in all cases. ${ }^{52}$

\section{Remedies under the PRA}

When the Matrimonial Property Act (MPA) was adopted in 1976, s 44 gave the court the power to set aside dispositions made to defeat a spouse's rights under the MPA. While a "disposition" was broadly interpreted, ${ }^{53}$ proving the required defeating intent was notoriously difficult, because the applicant had to establish a fraudulent motive. ${ }^{54}$ The intent requirement still imposes a hefty burden on applicants, even though there is no longer a need to establish a fraudulent motive. In Regal Castings $v$ Lightbody the Supreme Court held, in a different but similarly worded context, that a defeating intent exists if the transferor knew or must have known that the disposition would, or was likely to, defeat the applicant's rights. ${ }^{55}$ That test has since been applied to s $44 .{ }^{56}$ While the knowledge test makes it a little easier to establish a defeating intent, this requirement still constrains the usefulness of this remedy.

A Ministerial Working Group, established in 1988, identified the defeating effect of trusts on the MPA's equal sharing regime and proposed amendments to the MPA that included giving the courts

50 At $\mathrm{n} 81$.

51 At [79].

52 The reasonable expectation test, developed in Gillies $v$ Keogh [1989] 2 NZLR 327 (CA) and Lankow v Rose [1995] 1 NZLR 277 (CA), is also sometimes invoked in support of a constructive trust claim to a share of the beneficial ownership of trust assets: Clark v Clark [2012] NZHC 3159, [2013] NZFLR 534; Murrell v Hamilton [2014] NZCA 377; and MJK v HBTCL [2014] NZHC 3298. The fundamental flaws in these arguments are discussed by Rickett, above $\mathrm{n} 30$.

53 It includes all forms of alienation whether for value or not, and regardless of the status of the property and regardless of who disposes of the property: Re Polkinghorne Trust (1988) 3 FRNZ 636 (HC).

54 Coles $v$ Coles (1987) 3 FRNZ 101 (CA), where the Court of Appeal ruled that the applicant had to show a conscious desire to put the property beyond the court's reach.

55 Regal Castings Ltd v Lightbody [2008] NZSC 87, [2009] 2 NZLR 433, which concerned the power to set aside fraudulent dispositions under s 60 of the Property Law Act 1952.

56 Ryan v Unkovich [2010] 1 NZLR 434 (HC) at [33]; Patterson v Davison [2012] NZHC 2757; Gray v Gray [2013] NZHC 2890; and SMWv MC [2013] NZHC 396, [2014] NZFLR 71. 
the power to make orders against the capital of the trust to compensate for the loss of relationship property. Section 44C of the PRA, inserted as part of the regime's 2001 reforms, went some way to implementing the Working Group's recommendations, but stopped short of giving the courts power to make orders against the trust capital. That was intentional, because "trusts are created for legitimate reasons and should be permitted to fulfill that purpose, where there was no intention to defeat the spouse's claim at the time the trust was established". ${ }^{57}$

Section $44 \mathrm{C}$ empowers the court to order the respondent spouse or partner to compensate the applicant if either or both of them have disposed of relationship property to a trust since the relationship began and the disposition has the effect of defeating the rights of one of the spouses or partners under the PRA and s 44 is not available. The purpose of s $44 \mathrm{C}$ is to remedy the unequal effect of a disposition of relationship property. If both parties are equally affected by the disposition, there is no reason or justification to order one party to compensate the other. If the jurisdictional requirements are met, the court may order the other spouse or partner to pay a sum of money or transfer property from his or her separate property or relationship property. ${ }^{58}$ If there is insufficient property outside the trust, the court may order the trustees to pay income from the trust to the spouse or partner whose rights have been defeated by the disposition. ${ }^{59}$ The court cannot make an order against the trustees if a third person has in good faith altered their position in reliance on the ability of the trustees to distribute income under the trust and it would be unjust to make the order. ${ }^{60}$

Section $44 \mathrm{C}$ has not provided the much anticipated relief to disadvantaged spouses and partners. Its jurisdictional requirements provide only a narrow gateway into its compensation powers. Property transferred into trust prior to the start of the relationship or separate property of the owning spouse or partner is excluded, even if subsequently such property or its increase in value would have become relationship property. For example, if the family home was transferred into trust before the relationship began, the court has no jurisdiction to order compensation. ${ }^{61}$ Property transferred into trust by third parties, such as a third party vendor of the property or the parents of a spouse or partner, is not within the section's scope either. ${ }^{62}$

Furthermore, there may be no property or insufficient property outside the trust to compensate the applicant. ${ }^{63}$ The repeal of gift duty has removed the need to structure the settlement of trusts as a

57 Matrimonial Property Amendment Bill 1998 (109-1) (select committee report) at xii.

58 Property (Relationships) Act, s 44C(2)(a).

59 Property (Relationships) Act, ss 44C(2)(c) and 44C(3)(a).

60 Property (Relationships) Act, s 44C(3)(b).

61 Bourneville v Bourneville [2008] NZCA 520, [2009] NZFLR 69; and JEF v GJO [2012] NZHC 1021.

62 Genc v Genc (2006) 26 FRNZ 67 (HC); and Strauss v Turner [2014] NZHC 661.

63 For example in Ward $v$ Ward FC Hastings FAM-2004-020-116, 20 April 2007 the debt back to the spouses was partially forgiven and the value of the property transferred into trust had risen considerably since it was 
sale with a gradual forgiveness of the debt back. ${ }^{64}$ Property owners can now fully divest themselves of property in one go. While the court may order the trustees to pay income to the applicant in the absence of property outside to trust, ${ }^{65}$ the trust may not produce an income, or insufficient income, to compensate the applicant within a reasonable time frame. ${ }^{66}$

The PRA remedies are thus of limited use in redressing the adverse effects of trusts on the relationship property entitlement of spouses or partners.

\section{B Section 182 of the Family Proceedings Act 1980}

Section 182 of the Family Proceedings Act 1980 (FPA) dates back to s 37 of the Divorce and Matrimonial Causes Act 1867, when the court was first given the power to make orders in respect of nuptial settlements in proceedings ancillary to divorce proceedings. Those were the days of matrimonial unity, marriage settlements and fault-based divorce. Although much has changed since then, the power to make orders in respect of nuptial settlements on divorce has been retained. Section 182 can be invoked on the dissolution of a marriage or civil union. It is not available when a de facto relationship ends.

Although s 182 deals with property on the dissolution of a marriage or civil union, it is not part of the PRA and the presumption of equal sharing therefore does not apply. ${ }^{67}$ Section 182 serves a different purpose from ss 44 and $44 \mathrm{C}$ in the PRA. ${ }^{68}$ Whereas the PRA remedies are aimed at restoring the applicant's relationship property entitlement, s 182 is concerned with the applicant's provision from a nuptial settlement, which may not include assets produced by the couple. ${ }^{69}$

Section 182 involves a two stage process. ${ }^{70}$ The first stage is to determine whether the trust in question is a nuptial settlement. The second stage is to assess whether and, if so, how the court's discretion under s 182 should be exercised. ${ }^{71}$ For a trust to qualify as a nuptial settlement, it must

settled on trust. As the trust did not produce sufficient income, Mrs Ward applied for an order under s 182 of the Family Proceedings Act 1980.

64 Taxation (Tax Administration and Remedial Matters) Act 2011, s 245.

65 Property (Relationships) Act, s 44C(3); and Greig v Hutchison [2015] NZHC 1309, [2015] NZFLR 587.

66 As in Ward $v$ Ward, above $\mathrm{n} 63$.

67 Clayton CT (SC), above n 6, at [65], agreeing on this point with the Court's earlier decision in Ward $v$ Ward [2009] NZSC 125, [2010] 2 NZLR 31 at [20].

68 Clayton $C T(\mathrm{SC})$, above n 6, at [98]

69 At [61]-[64].

70 At [27].

71 The lower courts in Clayton $v$ Clayton had wrongly conflated the two stages when dealing with the Claymark Trust, concluding that the trust was a business trust from which Mrs Clayton did not expect to derive a benefit: Clayton $C T$ (SC), above n 6, at [30]. 
make some ongoing provision for one or both of the parties to a marriage or civil union in their capacity as spouses or civil union partners, with or without provision for their children. ${ }^{72}$ In its separate judgment in Clayton v Clayton on the Claymark Trust (Clayton CT), the Supreme Court held that a settlement for the parties "in their capacity as spouses" merely required there to be a connection or proximity between the settlement and the marriage. ${ }^{73}$ That connection is almost inevitable where there is a family trust settled during the currency of a marriage with either or both parties to the marriage being beneficiaries, as was the case in both Ward $v$ Ward and the Claymark Trust in Clayton $C T$. $^{74}$

The Supreme Court went on to say that the relevant connection might even exist where the trust was settled by a third party with a significant number of other beneficiaries, apart from the parties to the marriage, or where the trust was settled long before the marriage and a future spouse is listed as a potential beneficiary but no particular spouse is in contemplation at the time of settlement. ${ }^{75}$ This view reflects the reasoning of Kiefel $\mathrm{J}$ in Kennon $v$ Spry, ${ }^{76}$ a decision of the High Court of Australia, which a full bench of the High Court of New Zealand declined to follow in Kidd v van den Brink. ${ }^{77}$ The Supreme Court expressed its view with appropriate caution, which suggests that the required connection should not be remote or tangential. Nonetheless, these dicta pave the way for a wider meaning of nuptial settlement than has previously been accepted. Trusts may therefore be a great deal more vulnerable to orders under s 182, regardless of who settled the trust or the source of the assets.

Once jurisdiction is established, the court's discretion is at large. It can make such orders with respect to the settlement as it thinks fit. Section 182 provides no criteria or guidance on how the discretion is to be exercised. When the provision was first introduced in 1867 , the discretion was commonly used to prevent the guilty spouse from continuing to benefit from the nuptial settlement. Since the abolition of fault based divorce, s 182 has been used to provide some ongoing benefit for the applicant spouse. ${ }^{78}$

In Clayton $C T$ the Supreme Court held that the starting point is that nuptial settlements are premised on the continuation of the marriage. If that premise ceases to apply and the applicant is no

72 At [33]; and Ward v Ward, above n 67, at [27].

73 Clayton CT (SC), above n 6, at [34].

74 Ward v Ward, above n 67, at [28]; and Clayton CT (SC), above n 6, at [39]-[42]. The Supreme Court overruled the lower courts' decisions that the Claymark Trust was not a nuptial settlement.

75 Clayton CT (SC), above n 6, at [35]-[36].

76 Kennon v Spry, above n 46, at [228]-[230].

77 Kidd v van den Brink HC Auckland, CIV-2009-404-4694, 21 December 2009 at [23].

78 For example Chrystall v Chrystall [1993] NZFLR 772 (FC). 
longer able to benefit from the settlement, a fundamental change has come about that might necessitate a review of the settlement. ${ }^{79}$

"The purpose of the discretion is to remedy the consequences of the failure of the premise of a continuing marriage." 80 To that end the applicant's likely position under the settlement if the marriage had continued must be compared to the applicant's likely position in respect of the settlement after dissolution of the marriage. The comparison is forward looking, not backward looking to the time of settlement, and takes into account all relevant circumstances. ${ }^{81}$

Factors relevant to the exercise of discretion include the terms of the settlement and how the trustees are likely to exercise their powers, the wider benefits to the family unit that the trust has provided or might have been expected to provide, the source and character of the assets, taking into account the current social context that parties to a marriage contribute in different but equal ways to the marriage and accumulation of assets. ${ }^{82}$ The interests of children, particularly dependent children, are a primary consideration. ${ }^{83}$ Indeed, orders can be made in their favour. ${ }^{84}$ The parties' subjective expectations of the settlement may be relevant, but are not determinative. ${ }^{85}$

Had Mr and Mrs Clayton not settled their claim, the Supreme Court would have exercised its discretion in Mrs Clayton's favour. ${ }^{86}$ She was benefiting directly from the trust and indirectly by distributions for the children's support. There was also the possibility of the Trustees exercising their discretion to make distributions to her in the future and she would have continued to enjoy the benefits that the Trust conferred on the family as a whole as well as the financial support it provided to the sawmilling business that generated income for the family. As the assets in the trust had been acquired during the marriage, the Court would have ordered that the Claymark Trust be split into two equal trusts, as it did in Ward $v$ Ward. ${ }^{87}$

79 Ward $v$ Ward, above n 67, at [15]; and Clayton CT (SC), above n 6, at [50].

80 Clayton CT (SC), above n 6, at [50].

81 At [50]. This formulation of the test differs from the test in Ward $v$ Ward, above $\mathrm{n}$ 67, at [25] which focused on the parties' reasonable expectations of the settlement at the time it was made. Although that test was expressed in general terms, it was intended to describe the application of s 182 to the circumstances in Ward: Clayton CT (SC), above n 6, at [47]-[52] per Glazebrook J and at [99] per Elias CJ.

82 Clayton CT (SC), above n 6, at [57]-[68].

83 At [67].

84 Family Proceedings Act 1980, s 182(1)

85 Clayton CT (SC), above n 6, at [48]. This is in contrast to how the Supreme Court ruling in Ward v Ward, above n 67, was construed. See n 81 above.

86 Clayton CT (SC), above n 6, at [75]-[84].

87 Clayton CT (SC), above n 6, at [83]. 
While the applicants in Clayton CT and Ward $v$ Ward were eventually successful in their application under s 182, the jurisdictional requirements may prevent other applicants from invoking the provision, notwithstanding the wider meaning of nuptial settlement suggested by the Supreme Court. Besides, it is still not available to de facto partners. Section 182 thus has its limitations.

\section{NEW ZEALAND LAW COMMISSION PROPOSED REFORMS}

\section{A Reforms to s 44C PRA and 182 FPA}

The Law Commission reviewed the Law of Trusts between 2009 and 2013. As part of this Review it produced five Issues Papers, ${ }^{88}$ a Preferred Approach Paper, ${ }^{89}$ and a final Report, entitled Review of the Law of Trusts - A Trusts Act for New Zealand. ${ }^{90}$ The Commission's approach to this review was to focus on core matters of trust law, rather than the interface between trusts and other policy areas. It made an exception in regard to relationship property, because many submitters had singled out ss 44 and $44 \mathrm{C}$ of the PRA as inadequate remedies to ensure a just division of assets produced or enhanced by the relationship. ${ }^{91}$ To meet at least some of those concerns, the Law Commission recommended amending s 44C PRA and s 182 FPA.

The Law Commission recommended that s 44C PRA be amended to give the court power to make an order requiring the trustees of the trust to pay to one spouse or partner a specified sum of money or transfer property from the trust to compensate the partner whose rights were defeated by the disposition of relationship property to the trust. Section $44 \mathrm{C}$ would otherwise remain unchanged. The jurisdictional requirements would continue to provide only a narrow gateway into the compensation power and the change of circumstance defence for beneficiaries of the trust and the factors relevant to the exercise of discretion in s $44 \mathrm{C}(4)$ would still apply. Consistent with previous amendments to the PRA, ${ }^{92}$ the amendment would apply to existing relationships from the date that the amendment came into force, other than those relationships where the hearing of proceedings had already commenced. ${ }^{93}$ The power would therefore apply to dispositions of relationship property made before and after the amendment came into effect.

88 Law Commission Review of Trust Law in New Zealand: Introductory Issues Paper (NZLC IP19, 2010); NZLC IP10, above n 1; Law Commission Perpetuities, Revocation and the Variation of Trusts: Review of the Law of Trusts Third Issues Paper (NZLC IP22, 2011); Law Commission The Duties, Office and Powers of a Trustee: Review of the Law of Trusts Fourth Issues Paper (NZLC IP26, 2011); and Law Commission Court Jurisdiction, Trading Trusts and Other Issues: Review of the Law of Trusts Fifth Issue Paper (NZLC IP 28, 2011).

89 Law Commission Review of the Law of Trusts: Preferred Approach (NZLC IP31, 2012).

90 NZLC R130, above n 7.

91 NZLC IP31, above n 89, at [17.2]; and NZLC R130, above n 7 at [19.1].

92 Property (Relationships) Act, ss 4C, 10A-10D, 55, and 96-99.

93 NZLC R130, above n 7, at [19.29]. 
In regard to s $182 \mathrm{FPA}$, the Law Commission recommended that it be amended to apply to de facto relationships as well. ${ }^{94}$ The triggering event for all relationships should be factual separation, rather than legal dissolution, and the reference to nuptial settlement should be changed to relationship settlement. This amendment would remove the discrimination against de facto relationships as well as the need for spouses and civil union partners to wait two years for a formal dissolution of their legal bond. ${ }^{95}$

The amendments to s 44C PRA and s 182 FPA should apply to all relationships existing at the time that the amendments come into effect or commencing thereafter, unless proceedings had commenced at the time that the amendments came into force. ${ }^{96}$

\section{B Problems with the Law Commission's Proposed Reforms}

Problems with the Law Commission's proposed reforms are best explained by reference to three typical types of family trust.

(1) The Couple's Trust was settled by Conrad and Claire during their relationship with relationship property and an inheritance from Conrad's father, which is Conrad's separate property. The Trust was settled for sound asset protection reasons, but not to deprive either partner of their enjoyment of the property. Section 44 PRA is therefore not in play.

(2) The Single's Trust was settled by Simon years before he met and married Sally. The purpose of the Trust was to preserve the property from a former relationship for his children and for asset protection reasons. The assets transferred into trust were Simon's separate property, but include a house that on marriage to Sally becomes their family home and property that increases in value in part as a result of Sally's direct and indirect actions.

(3) The Parents' Trust is settled by Grant's parents for the benefit of their children and grandchildren as part of a succession plan. The partners of the children and grandchildren are included in the class of discretionary beneficiaries. The Trust's major asset is a farm with housing for each of the children and their families. Years after the Trust was established, Grant marries Gwen. They live and work on the farm and raise their children there.

After ten years each of the couples separates. Conrad, Simon and Grant continue to live in the family home and benefit from the trust, while Claire, Sally and Gwen move into rented accommodation and receive no support from the trust. The women lodge proceedings seeking orders under s 44C PRA and s 182 FPA, as amended in accordance with the Law Commission's proposals.

\footnotetext{
94 At [19.38].

95 Family Proceedings Act, s 39.

96 NZLC R130, above n 7, at [19.29] and [19.45].
} 


\section{Section 44C PRA}

The proposed amendment to s $44 \mathrm{C}$ would assist Claire, but only in regard to the disposition of relationship property. She would meet the other jurisdictional requirements in regard to such dispositions. The disposition has the effect of defeating her rights under the PRA. But for the Trust, she would have shared equally in that property. ${ }^{97}$ If Conrad has no property outside the Couple's Trust, the court could compensate Claire by making orders against the trustees to pay her up to half the current value of the relationship property transferred into the Couple's Trust.

No order under s $44 \mathrm{C}$ could be made in respect of Conrad's inheritance transferred into trust. But if relationship property had subsequently been applied to the inherited property, Claire would be entitled to claim compensation for the current value of those dispositions of relationship property. She should also be able to claim compensation for any increase in value of the inherited property attributable to the application of those dispositions of relationship property. But for those dispositions into trust, the relationship property could have been invested in some other equally lucrative venture in which she would have shared equally. The dispositions thus defeat her rights to share in the increased value of Conrad's inheritance. Whether she could use s $44 \mathrm{C}$ to claim compensation for an increase in value attributable to her direct or indirect actions is less clear. Her actions are contributions to property, rather than dispositions of property. However, in view of the wide meanings given to "disposition" and "property", it is arguable that her actions constitute dispositions of relationship property, at least in the context of the PRA. ${ }^{98}$

If the court decided to award compensation by ordering the trustees of the Couple's Trust to pay Claire a capital sum or transfer property to her, she would be receiving the money or property free from the constraints of the Couple's Trust, while Conrad would continue to be bound by the Trust. Section $44 \mathrm{C}$ does not provide for resettlement of the trust. An order vesting capital or property in Claire would therefore not achieve the intended equality of benefit as between the spouses.

At a more fundamental level, the effect of a compensation order removing property from the trust is to reverse a prior alienation. One of the core elements of a trust is the alienation of the settlor's personal estate to the beneficiaries of the trust. Claire and Conrad are free to alienate their assets to a trust, ${ }^{99}$ and they would usually have done so after receiving legal advice about the effect and implications of settling a trust. ${ }^{100}$ In New Zealand trusts are normally not revocable, because that defeats the settlor's intention of divesting himself or herself of property. Settlors intend their

97 Nation $v$ Nation, above n 2, at [146].

98 Re Polkinghorne Trust, above n 53, at 640, held that "disposition" means all forms of alienation, whether for value or not. Clayton VPRT (SC), above n 5, construed "property" purposively and contextually.

99 Property (Relationships) Act, s 19.

100 Independent legal advice is seen as good practice, but it is not a legal requirement. 
disposition to be a permanent alienation. Yet, the effect of a compensation claim under s 44C would be to revoke up to half the settlement. The disposition of relationship property is therefore not safe and the trustees and beneficiaries of the trust cannot be confident that the trust property will remain intact. Commercial certainty and the interests of beneficiaries are thus jeopardised. ${ }^{101}$ Even distributions to beneficiaries made in accordance with the terms of the trust may not be safe from recovery. The recipient beneficiaries risk losing some or all of the distribution if they are unable to show that they had altered their position in reliance on the distribution and that it would be unjust to make an order that would disturb that distribution. ${ }^{102}$

The Single's and Parents' Trusts are less vulnerable to a s 44C claim. Sally and Gwen would not meet the jurisdictional requirements, at least not in regard to the initial transfers of property. In Sally's case, the property was transferred into trust before Simon and Sally commenced their relationship and the assets were his separate property at the time of the transfer. In Gwen's case the dispositions were made by Grant's parents, not by Grant, and the assets came from his parents. However, if the couples had subsequently used relationship property to increase the value of the trust assets, those contributions would meet the jurisdictional requirements and allow the court to make orders removing capital from the trusts. The same arguments made in relation to the increase in value of the Couple's Trust could be made in relation to the Single's Trust and even the Parents' Trust. The risk to commercial certainty and the interests of other beneficiaries is even greater in these Trusts than in the Couple's Trust. Removing capital from the Single's Trust and the Parents' Trust also undermines the legitimate purposes for which these trusts were created.

\section{Section 182 FPA}

Claire could also apply for an order under s 182 FPA. The Couple's Trust fits the conventional understanding of a nuptial settlement. It was settled during the marriage to provide for Claire and Conrad and their children by virtue of their marriage. ${ }^{103}$ The court could therefore exercise its discretion in favour of Claire and would not be constrained by the difficulties associated with $\mathrm{s}$ 44C's jurisdictional limitations. Under s 182 the court's concern is not to compensate for loss of relationship property, but rather to secure ongoing benefit from the nuptial settlement in the best way possible. It may do so by resettling some of the trust property on Claire or vesting capital in Claire, if that is more appropriate in the circumstances. As the trust included Conrad's inheritance,

101 Official Assignee v Wilson, above n 22 at [52], where the Court of Appeal set a high threshold for finding a sham to protect commercial certainty and the interests of beneficiaries. Certainty of property interests benefits society and economic prosperity: see Emily Chamlee-Wright (ed) The Annual Proceedings of the Wealth and Well-Being of Nations, 2009-2010 (Beloit College Press, Beloit (Wisconsin), 2010) where Hernando de Soto's work on economic property theory is discussed. He coined the phrase "dead capital" to describe property that is unproductive because it is held in defective forms.

102 Property (Relationships) Act, s 44C(3).

103 Clayton CT (SC), above n 6. 
the court may leave Conrad with a larger share of the property. However, if the inheritance was small or if it had been benefiting Claire as well, directly or indirectly, the court may favour equality.

Whether the Single's Trust and the Parents' Trust are nuptial settlements is less clear. Case law preceding the Supreme Court decisions in Clayton v Clayton would have ruled against these trusts being nuptial settlements. ${ }^{104}$ Neither Trust was settled to provide for a particular marriage. But Clayton $v$ Clayton leaves room for argument that a sufficient connection between the trust and the marriage can be established for the trusts to qualify as nuptial settlements. If so, orders could be made that would significantly interfere with the purpose of these trusts, and the legitimate expectations of the settlors and beneficiaries. That risk is mitigated if the nuptial element is construed to require a genuine connection between the trust and the relationship from which it can be clearly inferred that the trust was intended to make provision for the couple in question, even if the identity of the spouse or partner was not known at the time of settlement.

If $\mathrm{s} 182$ is amended as proposed by the Law Commission, it provides a more appropriate means of dealing with trusts when a relationship ends than s $44 \mathrm{C}$ does. Unlike s $44 \mathrm{C}$, s 182 applies only if the trust was intended to provide for the couple. There should therefore be no surprise if the court makes orders that ensure that premise is maintained, albeit in a different form. Section 182 respects the trust, whereas s $44 \mathrm{C}$ does not. The interests of children are also at the forefront of s 182, whereas under s $44 \mathrm{C}$ those interests are incidental. There are therefore good reasons to favour the Law Commission's proposed amendment to s 182 and to oppose its amendment of s 44C.

\section{FURTHER OPTIONS FOR REFORM}

The forthcoming review of the PRA may recommend more radical reform to empower the courts to make orders against trustees in any circumstances where the trust holds property that would be relationship property but for the trust. Claire would be entitled to compensation for any increase in value in Conrad's separate property that was attributable to her actions and Sally and Gwen could claim compensation from the Single's Trust and Parents' Trust for the loss of their half share of the family home and any increase in value of other property that was attributable to their actions or the application of relationship property. Logically they should also be entitled to compensation for any other claims they would have had if the assets had not been in trust, such as compensation for sustaining the other party's separate property and for economic disparity. ${ }^{105} \mathrm{Such}$ a change would give the court the power to ignore the substance of the trust and prioritise a party's relationship property entitlement over the trust.

The adverse consequences would not be confined to trusts settled by a couple during their relationship. Simon might safeguard the trust assets in the Single's Trust from claims by Sally by

104 Kidd v van den Brink, above n 77. See also Brooks v Brooks [1996] 1 AC 375 (HL).

105 Property (Relationships) Act, ss 15, 15A and 17. 
entering into an agreement prior to or at the start of their relationship to contract out of the PRA and clarify Sally's rights in relation to the trust assets. ${ }^{106}$ Sally would no doubt be advised against signing such a contract, as she would be forfeiting a relationship property entitlement. Even if she did sign the contract, it may eventually be set aside on grounds of serious injustice. ${ }^{107}$ That is even more likely if Conrad and Claire contracted out of the PRA, as they had already acquired relationship property rights when they transferred their assets into trust. ${ }^{108}$ Contracting out agreements are no guarantee that the assets will remain safe from a PRA claim.

Contracting out of the PRA is more difficult for Grant, because his parents settled the trust and he is merely a discretionary beneficiary of the Parents' Trust. Any claim that Gwen might make would be against the trustees of the Parents' Trust and would not necessarily involve Grant at all. The trustees of the Parents' Trust have no standing under the PRA to contract out of its provisions. Only spouses and partners, or persons contemplating entering into a marriage, civil union or de facto relationship, have the right under s 21 to contract out of the PRA. The Parents' Trust would therefore be vulnerable to a PRA claim from Grant's former wife and have no means of safeguarding the trust against her claim.

There is a tension between giving effect to the social objectives of a statutory property sharing regime when a relationship ends and upholding the right to private property and thus the right of property owners to deal with their property as they wish. The PRA allows spouses and partners to deal freely with their assets during their relationship, including alienating them to third parties. It has been respectful of such alienations, unless they were made to defeat the relationship property rights of a spouse or partner. Even the recent ruling of the Supreme Court in Clayton VRPT that treats powers in relation to a trust as property does not interfere with the alienation of the assets. That sort of constraint is common in other statutes protecting vulnerable persons, such as creditors. ${ }^{109}$ Even if the disposition was made with fraudulent intent, the property cannot necessarily be recovered if the transferees received the assets for value and in good faith or if they did not provide value but altered their circumstances in the bona fide belief that the alienation was properly made. ${ }^{110}$

The objective of the PRA is to distribute property owned by each of the parties between the parties. While the meaning of property may be construed widely to capture rights and interests that would not in other contexts constitute property, the scope of the PRA is confined to property owned

106 Section 21.

107 Section $21 \mathrm{~J}$.

108 Harrison v Harrison, above n 29.

109 See for example Property Law Act 2007; and Insolvency Act 2006.

110 Property (Relationships) Act 1976, s 44(2); Property Law Act 2007, s 349(2); and Insolvency Act 2006, s 208. 
by each party to the relationship on separation or death. Section $44 \mathrm{C}$ is the first exception to that confined scope. For good reason the exception has strict boundaries, both in terms of its jurisdiction and the compensation order that the court is empowered to make against trustees. The Law Commission's proposed amendment to $\mathrm{s} 44 \mathrm{C}$ goes much further. It allows the court to remove capital from the trust, thereby according greater priority to the relationship property entitlement over the interests of beneficiaries of the trust. When deciding whether to order compensation, the court is not directed to consider the interests of other beneficiaries, such as children of a former relationship or a parent or sibling of the spouse or partner. While their interests might be considered as part of "any other relevant matter", their omission suggests a disregard for beneficiaries other than the spouse or partner of the relationship. If Parliament decides to relax the jurisdictional requirements of $\mathrm{s} 44 \mathrm{C}$, the detriment to the trust and its beneficiaries will be even greater.

The Law Commission's proposed amendment to s 182 FPA is less problematic, provided the term "nuptial settlement" is not construed too widely. It respects the trust, the premise on which the trust was settled and the trust's other beneficiaries. It is nonetheless a remedy affecting property triggered by the ending of a relationship. There is merit in the criticism that s 182 should be repealed because the PRA is intended to be a complete code governing property division when a relationship ends. The relationship between s 182 and the PRA and whether s 182 should be retained are questions that the Law Commission has been asked to consider as part of its review of the PRA. ${ }^{111}$

In my view, there are good reasons to retain s 182 as a separate provision, not as part of the PRA. It acknowledges that the property is not beneficially owned by the parties to the relationship and, hence, should not be governed by the same principles that underpin a statute that governs distribution of property beneficially owned by the parties to the relationship. The subject matter of a nuptial or relationship settlement may not have been produced by the parties to the relationship. The settlement may have been made by the parents of a spouse or partner to provide for the couple. While such settlements may now be less common, it would be a mistake to presume that they did not occur at all. Parents commonly support their children in a variety of ways and, with the present high cost of housing, such support may become more common and be best provided by means of a trust. In today's climate, there may also be a reversal of roles. As parents live longer and re-partner later in life, children may be supporting their parents through settlements. Such settlements do not readily fit with the purpose and principles of the PRA, but some variation may nonetheless be required when the relationship they were intended to provide for ends. If $\mathrm{s} 182$ is retained as a separate provision, the inclusion of criteria would provide guidance for the court in the exercise of its discretion and certainty for settlors and beneficiaries as to the reliability of their settlements.

111 See the terms of reference in "Review of the Property (Relationships) Act 1976" (24 May 2016) Law Commission 〈www.lawcom.govt.nz〉. 


\section{CONCLUSION}

This article sought to outline some of the practical and conceptual difficulties in providing remedies against the capital of a trust to ensure that a disadvantaged spouse or partner is able to secure a just division of the fruits of the partnership. I have argued against amending the PRA to provide for orders against the capital of a trust in the absence of an intention to defeat the rights of a spouse or partner. I favour retaining s $182 \mathrm{FPA}$ as a separate provision and making it available on separation and to de facto partners, provided it is applied only to trusts that were settled to make provision for a particular relationship. In my view that amendment strikes an appropriate balance between property rights following the breakdown of a relationship and respect for trusts and private property generally.

The arguments I have expressed may seem conservative, anti-equality, and out of step with international developments where orders in respect of trusts are well established. I believe the arguments are nonetheless worth making, because any order that a court makes against trustees necessarily affects the rights and interests of third parties, some or many of whom may not be part of the nuclear family of the former couple. In deciding what powers to grant to the court in respect of trusts holding assets produced by the former partnership the rights of third parties must not be ignored.

The purpose of this article was to explore the impact that prioritising relationship property entitlements would have on trusts, the interests of beneficiaries and commercial certainty. Deciding where to strike the balance between these competing interests is a policy decision for Parliament. Wherever that balance is struck, there is likely to be dissatisfaction, but at least it will have been made as part of a democratic process, rather than through judicial rulings made without the benefit of argument as to the wider ramifications of such rulings. 